\title{
Atitudes linguísticas: percepção e avaliação de diferentes falares do Brasil
}

\section{Flavia C. P de Sousa*, Livia Oushiro}

\section{Resumo}

Esse estudo está inserido no campo da Sociolinguística Variacionista (Labov, 2008 [1972]), com foco na área de atitudes, percepção e avaliação linguísticas. É o resultado de dois anos de pesquisa e coleta de dados em universidades de Campinas. Muitos estudos apontam para as características do português brasileiro e descrevem diferentes aspectos presentes em variedades linguísticas de diversas regiões e níveis sociais com base em dados de produção linguística (Freitag et al, 2016), possibilitando encontrar fatores que influenciam a variação e a mudança linguística. Contudo, também é importante estudar a percepção que os falantes têm sobre diferentes variedades, ou seja, como eles acham que falam e como reagem diante de outras variedades linguísticas

\section{Palavras-chave:}

Percepção, avaliação, sotaques brasileiros.

\section{Introdução}

A língua falada contém características que permitem identificar membros de um grupo nacional, social ou cultural, e as atitudes de um ouvinte em relação aos membros de um determinado grupo podem ser generalizadas ao dialeto ou socioleto que eles usam. Portanto, reações avaliativas a uma língua falada devem ser similares àquelas provocadas quando ocorre interação com indivíduos que são percebidos como membros de um grupo que utiliza essa língua. Assim, ouvir uma língua provavelmente despertará características principalmente generalizadas ou estereotipadas do grupo.

Objetiva-se descrever os julgamentos atribuídos a essas variedades linguísticas. Ao mesmo tempo, também se busca contribuir com os estudos de crenças e atitudes sobre falares de diferentes regiões do Brasil.

\section{Resultados e Discussão}

No primeiro ano de pesquisa, utilizou-se como método para acessar os julgamentos dos participantes um questionário online. Os resultados mostraram diferentes perspectivas dos participantes em relação a ter ou não ter "sotaque", que essas avaliações dos participantes em relação a sotaques quase sempre se dão em relações de alteridade ("eu/meu local de origem" vs. "outros grupos/deslocamentos espaciais"), que as variáveis fonéticas são os fenômenos mais salientes para a caracterização, diferenciação e reconhecimento dos dialetos (sendo os traços mais mencionados a pronúncia de $/ \mathrm{r} / \mathrm{e} / \mathrm{s} / \mathrm{em}$ coda silábica, como por exemplo, o /r/ retroflexo para São Paulo, aspirado para Minas Gerais e - /s/ "chiado" para o Rio de Janeiro), e em menor proporção também mostram associações com a prosódia e gírias.

Figura 1. Nuvens de palavras com as características mencionadas do sotaque de MG, RJ e SP respectivamente

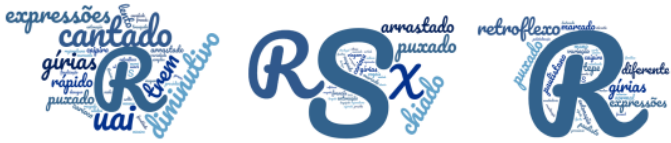

No segundo ano de pesquisa, foi utilizada como método a técnica matched-guise, que tem o objetivo de comparar as notas atribuídas à variáveis (altura, boa aparência física, liderança, senso de humor, inteligência, religiosidade, autoconfiança, confiabilidade, jovialidade, bondade, ambição, sociabilidade, caráter e simpatia) a um mesmo falante ouvido em seus diferentes "disfarces" (Lambert et al, 1960). Tendo controlado o conteúdo das falas e qualidade das vozes, quaisquer diferenças nas escalas para um mesmo falante poderiam ser atribuídas à língua do estímulo, e não ao falante em si.

\section{Conclusões}

O discurso que as pessoas têm sobre sotaque está voltado à percepção e possui uma relação de alteridade, sempre em contraste com a fala do outro.

\section{Agradecimentos}

PIBIC/CNPq - Quota 2017/2018; quota 2018/2019

Freitag, Raquel Meister Ko, et al. (2016) "Como os brasileiros acham que falam? Percepções sociolinguísticas de universitários do Sul e do Nordeste"; Todas as Letras-Revista de Língua e Literatura 18.2.

Labov, William (2008 [1972]). Padrões Sociolinguísticos. São Paulo: Editora Parábola. Tradução de Marcos Bagno, Maria Marta Pereira Scherre e Caroline R. Cardoso.

Lambert, W. E., Hodgson, R. C., Gardner, R. C., and Fillenbaum, S. (1960). Evaluational reactions tospoken languages.Itextit\{The Journal of Abnormal and Social Psychology\}, 60(1):44-51. 